\title{
H2BS1 Gene
}

National Cancer Institute

\section{Source}

National Cancer Institute. H2BS1 Gene. NCI Thesaurus. Code C162838.

This gene is involved in nucleosome remodeling and antimicrobial humoral responses. 